\title{
Status prawny kobiet w Polsce w świetle ustawodawstwa Unii Europejskiej
}

$W_{\text {stawowych wolności w wielu dziedzinach życia - zarówno poli- }}^{\text {dorobku cywilizacji Zachodniej kwestia praw człowieka oraz pod- }}$ tycznych i obywatelskich, a także społecznych i kulturowych - była niejednokrotnie akcentowana. Wedle zasady, każdy obywatel posiada bez względu na płeć - równe prawa, obowiązki i szanse w każdym aspekcie. Równouprawnienie oznacza równy podział władzy i wpływów, a więc prawo udziału kobiet w instytucjach i organach decyzyjno-opiniodawczych. Dotyczy także innych aspektów - prawa do niedyskryminacji w pracy, w odniesieniu do działalności gospodarczej oraz równych szans uzyskania niezależności finansowej.

Zagadnienia związane $\mathrm{z}$ równouprawnieniem oraz $\mathrm{z}$ sytuacją kobiet znalazły odzwierciedlenie w wielu regulacjach prawa międzynarodowego. „Już Karta NZ tak mocno zaakcentowała równouprawnienie mężczyzn i kobiet, a samą zasadę ochrony praw człowieka przeznaczała «dla wszystkich, bez względu na rasę, płeć, język lub religię. Poczynając od Deklaracji Powszechnej 1948 r., formuła równości i niedyskryminacji wzbogaca się o dalsze względy [...] i dopełnia się istotnym zwrotem końcowym lub jakikolwiek inny status (inne względy, czy inne okoliczności)». Zatem, nie ma takiego względu, który uzasadniałby dyskryminację"1. Kwestie, które uznawano niegdyś za ściśle wywodzące się z tradycji i obyczajów, stały się przedmiotem międzynarodowego ustawodawstwa i wielu unormowań. Podjęte działania miały urzeczywistnić postulat respektowania praw kobiet na całym świecie. „U podstaw poglądu sformułowanego $\mathrm{w}$ tego typu ustaleniach leży przekonanie o przyrodzonej równości ludzi, którzy w związku z tym powinni mieć szansę jej realizowania w odpowiednio zorganizowanym społeczeństwie"².

1 A. M. Świątkowski, Europejskie prawo socjalne, Warszawa 1999, rozdział V.

2 Por. J. Bator, Wizerunek kobiety w polskiej debacie politycznej, Warszawa 1999. 
Przyznanie zarówno przez prawodawstwo poszczególnych krajów, jak i przez wspólnotę międzynarodową równych praw dla kobiet i mężczyzn powinno zapewnić obu płciom równy status, jednak nie przekłada się to na praktyczną realizację zasady równouprawnienia, a kobiety w większości krajów wciąż spotykają się z przejawami dyskryminacji w wielu sferach życia.

Hipotezą niniejszej pracy jest twierdzenie, że pełna poprawa sytuacji prawnej kobiet w Polsce po przystapieniu do Unii Europejskiej wymaga wielu inicjatyw zarówno krajowych, jak i unijnych. W celu udowodnienia powyższej hipotezy sformułowano następujące pytania badawcze:

1. Na czym polega zasada równości i niedyskryminacji?

2. Jakie są instrumenty prawne Unii Europejskiej, które mogą wpłynąć na równouprawnienie kobiet?

3. Jaka jest skuteczność instrumentów prawnych wpływających na równość szans obu płci?

4. Jakie są przyczyny braku praktycznej realizacji zasady równouprawnienia?

5. Czym różni się sytuacja kobiet w Polsce od sytuacji kobiet w pozostałej części Unii Europejskiej?

6. Jakie zmiany dla sytuacji prawnej kobiet nastapiły od momentu przystapienia Polski do Unii Europejskiej?

7. Czy istnieje możliwość dalszej poprawy sytuacji kobiet w Polsce i pozostałych państwach członkowskich?

W celu rozwinięcia problemu posłużono się metodą politologiczną. W systemowym kreśleniu problemu istotne znaczenie miały elementy metodologii porównawczej, analizy instytucjonalno-prawnej oraz poznania historycznego ${ }^{3}$.

\section{Podstawy równouprawnienia płci}

Wspólnoty Europejskie, a następnie Unia Europejska, od początku wykazywały znaczne zainteresowanie zasadą równouprawnienia. „W latach pięćdziesiątych to zainteresowanie wynikało raczej z lęku przed nieuczciwą konkurencją niż z zaniepokojenia z powodu niekorzystnych warunków pracy kobiet. A jednak Unia Europejska stworzyła ważne

\footnotetext{
3 A. Chodubski, Wstęp do badań politologicznych, Gdańsk 1996, s. 72-82.
} 
strukturalne i instytucjonalne podstawy prowadzenia polityki równych szans w państwach członkowskich" ${ }^{\text {. }}$ W myśl ustawodawstwa unijnego, każde państwo jest zobowiązane do przyjęcia podstawowych norm cywilizacyjnych, do których należy akceptacja zasady równości i niedyskryminacji. Państwa zobowiązały się do zagwarantowania pełnej zgodności ustawodawstwa z prawem wspólnotowym do dnia uzyskania członkostwa w Unii Europejskiej.

Porównując wpływ regulacji unijnych na rozwiązania krajowe państw członkowskich, można stwierdzić, iż rozwiązania prawne dotyczące równouprawnienia mężczyzn i kobiet w przepisach europejskiego prawa pracy wywarły największy wpływ na uregulowanie odmiennych od dotychczasowych standardów. Zasada równego traktowania pracowników bez względu na płeć stanowi „fundament, na którym oparte były międzynarodowe organizacje jednoczącej się Europy: Europejska Wspólnota Gospodarcza, Wspólnoty Europejskie, Unia Europejska. Przepis art. 119 Traktatu Rzymskiego (art. 119 TR) wprowadził zasadę jednakowego wynagradzania pracujących mężczyzn i kobiet za jednakową pracę" 5 . Jednakże w art. 141 Traktatu Amsterdamskiego (art. 141 TA) z 1997 roku, zmieniono postanowienia Traktatu Rzymskiego i stworzono nowe podstawy prawne względem równouprawnienia kobiet i mężczyzn. „Zasada równouprawnienia została uznana za fundamentalne prawo Wspólnoty. Rada Unii Europejskiej została zobligowana do zwalczania każdego przejawu dyskryminacji na tle różnic płci, a państwa członkowskie zobowiązały się do eliminowania nierówności i wspierania równości pomiędzy mężczyznami i kobietami"“. Deklaracja 28 z Konferencji w Amsterdamie stanowi, iż państwa członkowskie zgodnie z art. 141 ust. 4 Konsolidowanych traktatów powinny użyć wszelkich środków, które mogłyby służyć poprawie sytuacji kobiet w życiu zawodowym ${ }^{7}$. Ponadto w postanowieniach art. 141 zapewniono zastosowanie zasady jednakowego wynagradzania obu płci przez państwa członkowskie. Równość zarobków oznacza wynagradzanie za jednakową pracę lub pracę jednakowej wartości dla tych samych stanowisk pracy, w oparciu o jednakową jednostkę wymiaru.

4 Ekonomia i pleć, po red. A. Geske Dijkstra, A. Plantega, Gdańsk 2003.

5 Por. A. M. Świątkowski, op. cit.

${ }^{6}$ ABC Unii Europejskiej, Warszawa 2004, rozdział 22, s. 1.

7 Por. S. Hambura, M. Muszyński, Karta Praw Podstawowych z komentarzem, Bielsko-Biała 2001, s. 122. 
Bogaty dorobek prawny Unii Europejskiej obejmuje wiele środków służących stworzeniu i utrwaleniu struktur zapewniających równe szanse dla obu płci, które różnią się dla państw członkowskich stopniem obligatoryjności. Do powyższych instrumentów należą dyrektywy, zalecenia oraz programy działania. „Dyrektywa nakłada na państwa członkowskie obowiązek wprowadzenia do krajowego ustawodawstwa odpowiednich zmian w określonym czasie, zgodnie z jej treścią i wymową. Zalecenia i programy działania mają na celu zainicjowanie i prowadzenie odpowiedniej polityki w poszczególnych państwach członkowskich. Oprócz dyrektyw, zaleceń i programów Unia Europejska stworzyła sieć jedenastu instytucji, z których każda jest odpowiedzialna za określony obszar problemowy"

\section{Dyrektywy}

W 1957 roku w traktatach EWG wprowadzono zasadę, że kobiety i mężczyźni powinni otrzymywać równą płacę za równą pracę. Od połowy lat 70-tych stopniowo poszerzano zakres ochrony przed dyskryminacją w ramach szeroko rozumianego zatrudnienia. Współcześnie unijne dyrektywy na rzecz równouprawnienia obejmują osiem aktów. W pierwszej dyrektywie 75/117/EWG zakazuje się jakiejkolwiek dyskryminacji ze względu na płeć przy ustalaniu wysokości wynagrodzeń. W postanowieniach aktu rozwinięto i wprowadzono pojęcie „równej płacy za pracę tej samej wartości”.

Jak słusznie zauważa Anneke van Doorne-Huiskes, sformułowanie „praca równej wartości”, jako pojęcie nieostre, kryje w sobie wiele niebezpieczeństw związanych z nadużyciami. „Wartość przypisywana określonej pracy jest bowiem często zdeterminowana przez właściwe dla danej organizacji systemy klasyfikacji poszczególnych prac" ${ }^{\prime 9}$. Mimo, iż dyrektywa została wprowadzona przeszło 30 lat temu, nadal nie udało się wyrównać poziomu płac dla obu płci. Według europejskiej średniej, kobiety będąc na tych samych stanowiskach, zarabiają od 70-90\% wynagrodzeń wypłacanych mężczyznom. W wielu krajach dysproporcja w zarobkach jest jeszcze większa i sięga nawet 33\%. Przyczynę upatruje się w spełnianej przez kobiety roli w społeczeństwie. Rodzenie i wychowywanie dzieci

8 Ekonomia i pleć ..., s. 138.

9 Ibidem, s. 138. 
prowadzi do przerwy od pracy zawodowej na okres kilkumiesięczny, a nawet kilkuletni, co może negatywnie wpływać na wynagrodzenie.

W opinii EKES opieka nad dzieckiem niejednokrotnie oznacza krótszy okres pracy na stałym etacie, a w rezultacie mniejsze doświadczenie, utrudnienia w uzyskaniu podwyżki oraz ograniczenia w dostępie do szkoleń. „Profil kariery zawodowej z długą przerwą na opiekę nad dzieckiem jest częstszy w przypadku matek z wykształceniem na niższym poziomie. O ile matki z wyższym wykształceniem skróciły okres przerwy w pracy zawodowej, o tyle u kobiet o niskich kwalifikacjach nic się nie zmieniło. Zwykle pozostają one poza obrębem rynku pracy do czasu, aż dziecko pójdzie do szkoły. Dlatego też kobiety gorzej wykształcone ponoszą największe straty finansowe"10.

Drugą dyrektywą zajmującą się zagadnieniami dostępu do pracy, szkolenia i awansu zawodowego oraz właściwych warunków zatrudnienia, jest dyrektywa 76/207/EWG dotycząca równego traktowania kobiet i mężczyzn na rynku pracy. Uważana jest za mającą podstawowe znaczenie dla zasady równouprawnienia i będącą przejawem dynamicznego podejścia instytucji wspólnotowych do zagadnień zapewniających równe szanse na rynku pracy obu płciom. Potwierdzeniem jest art. 3 ust. 2 lit. C dyrektywy, który stanowi, iż „na władze państw członkowskich Unii Europejskiej oraz partnerów społecznych nałożony został obowiązek systematycznego dokonywania przeglądu obowiązujących przepisów w celu stwierdzenia, czy dyferencjacja oparta na kryterium płci jest nadal rzeczowo uzasadniona"11. W postanowieniach aktu zdefiniowano równe traktowanie kobiet i mężczyzn jako zakaz wszelkiej dyskryminacji pracowników oraz kandydatów do pracy ze względu na płeć, stan cywilny lub rodzinny. Zakaz obejmuje dyskryminację bezpośrednią, czyli sytuację „kiedy kobiety i mężczyźni są traktowani w różny sposób, nie mający obiektywnego i racjonalnego uzasadnienia, a powodem różnego traktowania jest płeć"12 oraz pośrednią, która ma miejsce, ,gdy prawo, przepis prawny, polityka lub praktyka, pozornie neutralne, mają negatywne skutki dla znaczącej liczby przedstawicieli jednej płci, chyba że stosowanie takiego uregulowania, kryterium lub praktyki jest właściwe i niezbędne, a także może być usprawiedliwione czynnikami nie związanymi z płcią"13.

10 M. Mendza-Drozd, Opinia EKES dotyczqca ubóstwa kobiet $w$ Europie, www.ue.ngo.pl.

11 A. M. Świątkowski, op. cit., s. 146.

12 www.federa.org.pl.

13 Ibidem. 
Jednakże zgodnie z art. 141.4 TA niezgodne z prawdą jest twierdzenie, że płeć nie może być w określonych przypadkach czynnikiem determinującym dostęp do zawodu. „Sprawiedliwość społeczna wymaga, aby postępując zgodnie z zasadą równouprawnienia - różnicować pracowników, stwarzając im nierówne szanse, odwrotnie proporcjonalne do ich wcześniejszej sytuacji”"14. W przepisach wspólnotowych zakazano dyskryminacji ze względu na płeć w zakresie warunków tworzenia działalności gospodarczej (dyrektywa 86/613/EWG). W postanowieniach aktu rozciągnięto zasadę równego traktowania na kobiety, które są pracodawcami, pracują na własny rachunek lub pracują ze swymi współmałżonkami.

Kolejna dyrektywa ( 79/7/EWG) dotyczy wdrażania zasady równego traktowania kobiet i mężczyzn do systemów zabezpieczenia społecznego. Odnosi się do ustawowych regulacji na wypadek choroby, inwalidztwa, starości, wypadku przy pracy, choroby zawodowej i bezrobocia oraz w sferze pomocy społecznej. Dyrektywa 79 została uzupełniona przez dyrektywę 86/378/EWG dotyczącą systemów społecznego zabezpieczenia zawodowego, w której odniesiono się do pracowników oraz osób pracujących na własny rachunek z określonej grupy przedsiębiorstw i sektorów rynku pracy. W postanowieniach obu dyrektyw zakazano dyskryminacji bezpośredniej i pośredniej w dostępie do systemów ubezpieczenia społecznego, obowiązku obliczania i płacenia składek, obliczaniu wysokości i ustalaniu długości okresu udzielania świadczeń. Jednocześnie z opowiedzeniem się przeciwko ujednoliceniu w krajach członkowskich wieku emerytalnego, wprowadzono zapis, który stanowi, iż wcześniejsze przejście na emeryture jest dla kobiet prawem, a nie obowiązkiem.

Następne dyrektywy dotyczą ochrony kobiet, które zdecydowały się na macierzyństwo. W dyrektywie $92 / 85 /$ EWG, w sprawie „ochrony pracownic w ciąży, tych, które urodziły dziecko albo karmią piersią", zapobieżono rozwiązaniu umowy $\mathrm{z}$ pracownicą będącą $\mathrm{w}$ okresie ciąży i urlopu macierzyńskiego przy jednoczesnym nakazie stworzenia bezpiecznych warunków w miejscu pracy. Akt stanowi zbiór minimalnych zabezpieczeń, który jednakże pozostawia państwom członkowskim możliwość zastosowania odmiennych rozwiązań, pod warunkiem, że nie ograniczono by zakresu podstawowej ochrony. W dyrektywie 96/34/WE uregulowano kwestię urlopów rodzicielskich. W postanowieniach aktu

14 A. M. Świątkowski, op. cit., s. 141. 
stwierdzono, iż do ukończenia przez dziecko 8 roku życia, oboje rodzice mają prawo skorzystać z co najmniej trzymiesięcznego urlopu. Po wykorzystaniu przyznanego okresu mają prawo powrotu na to samo lub równorzędne stanowisko.

W dyrektywie 97/80/WE przyspieszono drogę sądową w sprawach dotyczących dyskryminacji ze względu na płeć oraz umożliwiono jak najszybsze zażegnanie konfliktów i ewentualny powrót kobiet do pracy. Ciężar udowodnienia zarzutu został przeniesiony na obwinionego, który ma obowiązek wykazać, iż swoim zachowaniem nie naruszył zasady równego traktowania pracowników ze względu na płeć. Do poszkodowanej pracownicy należy jedynie przedstawienie faktów, które mogą uprawdopodobnić zasadność zarzutu.

Ostatnia z dyrektyw, przyjęta w maju 2001 roku, zakazuje molestowania seksualnego w miejscu pracy. Stanowi rozwinięcie wydanego w 1992 roku przez Komisję Europejską „Kodeksu etycznego postępowania w stosunkach pracy".

\section{Zalecenia}

Zalecenie w sprawie promowania działań pozytywnych na rzecz kobiet zostało przyjęte w grudniu 1984 roku przez Radę Wspólnot Europejskich. Należąc do tzw. kategorii soft law ma za zadanie rekomendację państwom członkowskim inicjację działań politycznych, które przyczyniłyby się do likwidacji nierówności na rynku pracy (np. poprzez działania na rzecz podniesienia świadomości czy kampanie informacyjne). Zalecenia stanowią apel o wyeliminowanie dyskryminacji, której kobiety doświadczają w niemal każdej dziedzinie życia, przez przyjęcie działań pozytywnych i promowanie „wymieszanych” zawodów. Działania pozytywne „należy rozumieć jako narzędzie polityczne, które pozwala zredukować i/lub złagodzić różne ograniczenia w możliwościach robienia kariery zawodowej przez kobiety"15. Służą ponadto aktywnej promocji kobiet, które poprzez realizację w sektorach oraz na szczeblach przedsiębiorstw, pozwalają w określonych przypadkach automatycznie faworyzować kobiety. Jednakże mimo podjęcia w wybranych krajach europejskich działań pozytywnych, sytuacja kobiet poprawiła się w niewielkim stop-

15 Ekonomia i płeć ..., s. 141. 
niu. Ponownie główną przyczyną wydaje się być nadmiar obowiązków domowych i związanych z opieką nad dziećmi. Pominięcie kwestii proporcjonalnej reprezentacji kobiet i mężczyzn było powodem znacznego osłabienia siły działań pozytywnych jako unijnego instrumentu. W strukturach UE nie wypracowano, prócz ustawodawstwa mającego na celu równouprawnienie płci, jakichkolwiek mechanizmów, które miałyby służyć monitorowaniu sytuacji kobiet. „W rezultacie rządy poszczególnych państw członkowskich UE mają decydujący głos w sprawie działań podejmowanych w ich krajach na rzecz kobiet" $"$.

\section{Programy}

W ramach Wspólnot Europejskich, od 1980 roku zaczęto tworzyć wieloletnie programy, które podobnie jak działania pozytywne, mają na celu złagodzenie ekonomicznych, społecznych i kulturowych ograniczeń oraz redukcję negatywnego wpływu różnych uwarunkowań na sytuację kobiet na rynku pracy oraz ich karierę zawodową. Finansowanie programów powierzono głównie Europejskiemu Funduszowi Społecznemu. Spośród realizowanych cyklicznie programów działania najważniejszym jest Średnioterminowy Program na rzecz Równych Szans Kobiet i Mężczyzn, którego postanowienia są akceptowane zarówno przez Komisję Europejską oraz państwa członkowskie. „Piąta edycja programu na lata 2001-2005 ma następujące cele strategiczne:

- działania na rzecz równości w życiu ekonomicznym i gospodarczym,

- wspieranie równego udziału i reprezentacji w procesach podejmowania decyzji,

- zapewnianie równości w życiu społecznym,

- zwalczanie stereotypów,

- upowszechnianie równości w życiu politycznym i obywatelskim,

- włączanie problematyki praw kobiet do wszystkich programów politycznych UE związanych z jej rozszerzeniem" "17.

Kwestia równego udziału kobiet i mężczyzn w procesach podejmowania decyzji, która oznacza równą reprezentację obu płci w instytucjach państwowych, na stanowiskach kierowniczych, w sądownictwie, szkolnictwie wyższym i innych instytucjach życia publicznego, zajmuje w V edycji

\footnotetext{
16 Ibidem, s. 23 i 142.

17 ABC Unii Europejskiej ..., rozdział 22, s. 4.
} 
programu strategiczne miejsce. „Uznaje się, że przyczyny nieobecności kobiet w polityce mają różnorodny charakter: kulturowy, społeczny, ekonomiczny oraz polityczny. Przyczyny kulturowe mieszczą się w stereotypie, iż polityka to męski obszar aktywności. Społeczne - dotyczą ról, które kobieta spełnia; podwójnych ról - zawodowej i domowej. Z przyczyn ekonomicznych kobiety są mało atrakcyjnym dla partii partnerem wyborczym, gdyż nadal jeszcze zarabiając mniej od mężczyzn, nie wnoszą zaplecza ekonomicznego. I na koniec - przyczyna polityczna, którą stanowią selekcje wewnątrzpartyjne"18. Rozważana jest obecnie kwestia parytetów wyborczych, które zagwarantowałyby minimum 40\% udział każdej płci w organach władzy publicznej. Zapewniono by rzeczywistą reprezentację oraz możliwość wyboru, a jednocześnie zwiększono by udział kobiet w administracji rządowej. Niestety, żaden akt prawny nakazujący państwom członkowskim stosowanie systemu parytetowego nie powstał. Z własnej inicjatywy zastosowana została do chwili obecnej tylko w Szwecji. Polityka kadrowa w administracji rządowej Szwecji polega na przedstawieniu przez dane ministerstwo, w przypadku wakatu, dwóch kandydatów - zarówno kobiety, jak i mężczyzny. Jeżeli dojdzie do sytuacji, w której obaj kandydaci charakteryzują się identycznymi kwalifikacjami, dokonuje się tzw. selekcji pozytywnej. Działanie polega na wyborze kobiety, jednakże tylko w sytuacji, gdy na stanowiskach kierowniczych przeważają mężczyźni.

Pozostałe programy unijne na rzecz równouprawnienia to m.in.: Daphne (dotyczący zwalczania przemocy w stosunku do dzieci, młodzieży oraz kobiet), Zero Tolerancji (mający głównie na celu zapobieganie przemocy wobec kobiet, zapewnienie kobietom skutecznej ochrony przed przemoca oraz realnego wsparcia ze strony specjalnie do tego powołanych instytucji), Stop (którego główne zadanie stanowi przeciwdziałanie handlu kobietami oraz pomocy kobietom, które zmuszane są do prostytucji) oraz Leonardo da Vinci (mający na celu wspieranie kształcenia i szkolenia zawodowego).

\section{Instytucje}

Wśród wielu instytucji Unii Europejskiej funkcjonują także organy zajmujące się problematyką równouprawnienia. Instytucje stojące na straży

18 Por. S. Spurek, Kobiety, partie, wybory, Łódź 2002. 
równych praw kobiet i mężczyzn istnieją ponadto we wszystkich krajach członkowskich UE. W Komisji Europejskiej zagadnieniami równości płci zajmuje się od 1976 roku Dyrekcja Generalna V (do spraw Polityki Społecznej i Zatrudnienia) - Wydział Równych Szans oraz Polityki Rodzinnej. Jest odpowiedzialny za pilnowanie, by w dziedzinach, jakimi zajmuje się Komisja Europejska, nie umieszczono jakichkolwiek elementów, które mogłyby dyskryminować ze względu na płeć. Powierzono mu obowiązek „monitorowania ustawodawstwa dotyczącego równej płacy, równego traktowania $\mathrm{w}$ dostępie do pracy, równego traktowania osób pracujących na własny rachunek oraz zdrowia i bezpieczeństwa pracownic w ciąży"19. W Wydziale Równych Szans prowadzone są również działania na rzecz poprawy statusu kobiet w społeczeństwie i na rynku pracy, a wspólnie z Wydziałem Polityki Rodzinnej przygotowywane i prowadzone są programy działań na rzecz równych szans. Zaś Wydział do spraw Zabezpieczenia Społecznego, Ochrony Socjalnej i Warunków Życia odpowiada za monitorowanie ustawodawstwa dotyczącego dwóch dyrektyw w sprawie zabezpieczenia społecznego. Dyrekcja Generalna V powołała ponadto grupy ekspertów, z których jedna zajmuje się monitorowaniem zmian prawnych dotyczących równouprawnienia płci, a kolejna - analizą sytuacji kobiet na rynku pracy. W Dyrekcji zajmującej się informacją, komunikacją, kulturą i mediami działa Wydział Informacji o Sprawach Kobiet.

Drugą z instytucji jest Komisja Praw Kobiet i Równych Szans przy Parlamencie Europejskim. Komisja składa się z 40 członków reprezentujących wszystkie partie Parlamentu Europejskiego. Głównym zadaniem Komisji jest rozwijanie sytuacji prawnej kobiet w państwach członkowskich, a zarazem propagowanie standardów unijnych w państwach pozaczłonkowskich. „Komisja zajmuje się również oceną politycznych strategii dotyczących praw kobiet. Jej autorstwa jest ponadto kilkanaście różnych rezolucji dotyczących praw kobiet, a przyjętych przez Parlament Europejski. Wraz ze wzrostem roli PE w tworzeniu prawa wspólnotowego Komisja Praw Kobiet i Równych Szans podejmuje inicjatywy legislacyjne. Ostatnią z nich jest przygotowanie projektu dyrektywy zakazującej mobbingu (systematycznego i złośliwego dokuczania ze strony szefa)"20. Parlament Europejski przygotowuje również raporty w sprawie sytuacji

\footnotetext{
19 Por. Ekonomia i płeć ..., rozdział 9.

${ }^{20}$ ABC Unii Europejskiej ..., rozdział 22, s. 4.
} 
kobiet w krajach Unii i w innych oraz w sprawie rozszerzenia Unii Europejskiej. W każdej instytucji unijnej funkcjonuje ponadto Komitet ds. Równych Szans.

Wśród instytucji zmierzających do uzyskania faktycznej równości praw kobiet i mężczyzn znajduje się ponadto Komitet Sterujący do spraw Równości Kobiet i Mężczyzn. Został utworzony w 1987 roku przy Radzie Europy w celu badania sytuacji i oceniania postępów w dziedzinie równouprawnienia obu płci w krajach członkowskich, przeprowadzania różnorodnych analiz, opracowywania i oceniania strategii politycznych oraz promowania współpracy zmierzającej do osiagnnięcia rzeczywistej równości płci. Główne obszary zainteresowania Komitetu obejmują:

- ,zwalczanie handlu ludźmi w celu wyzysku seksualnego,

- zwalczanie przemocy wobec kobiet,

- »gender mainstreaming« [...]

- zwiększanie roli kobiet w sprawowaniu władzy"21.

Podstawą działania Komitetu Sterującego stanowi deklaracja Komitetu Ministrów Rady Europy z 1988 roku, która stanowi, że ,zasada równości kobiet i mężczyzn stanowi integralną część praw człowieka i że dyskryminacja ze względu na płeć jest zasadniczą przeszkodą w efektywnym korzystaniu przez jednostki z fundamentalnych praw człowieka. Innymi słowy, równość została przeniesiona z płaszczyzny żądań stawianych przez kobiety w ich własnym interesie na płaszczyznę praw człowieka"22.

\section{Europejski Trybunał Sprawiedliwości}

Przy omawianiu wpływu na rozwój zasady równouprawnienia, nie można pominąc roli licznych wyroków Europejskiego Trybunału Sprawiedliwości. Trybunał zajmował się interpretacją poszczególnych przepisów i nakłanianiem państw członkowskich do wdrażania standardów zawartych w traktatach i dyrektywach. W orzeczeniach można zauważyć wyraźnie jedną z dwóch tendencji: „stosowania jednolitych, tzn. »męskich«, standardów w stosunkach pracy (equality and the male norm) lub różnicowania sytuacji pracujących kobiet ze względu na płeć. W spra-

21 M. Krzyżanowska-Mierzewska, Zakaz dyskryminacji W Europejskiej Konwencji o Ochronie Praw Człowieka i Podstawowych Wolności. Poradnik dla skarżacych, Warszawa 2005, s. 14.

22 Ibidem, s. 15. 
wach z zakresu prawa pracy niemal nie spotyka się orzeczeń, w których płeć traktowana byłaby przez Europejski Trybunał Sprawiedliwości jako czynnik neutralny (equality as neutrality) ${ }^{\$ 23}$. Do pierwszych przypadków można zaliczyć porównanie przez ETS długotrwałej choroby mężczyzny $\mathrm{z}$ ciążą i macierzyństwem jako przeszkodą w wykonywaniu pracy przez kobietę, czy też zastosowania jednolitych standardów wobec mężczyzn i kobiet, opartych na natężeniu wysiłku wymaganego do wykonania określonych prac. Do tendencji nie uznającej możliwości stosowania norm opartych na standardach wypracowanych do porównania oceny pracy mężczyzn do kobiet i ich pozycji w stosunkach pracy, można zaliczyć orzeczenie, iż pracodawca ma prawo odmówić kobietom funkcjonariuszom policji, ze względów bezpieczeństwa, prawa do noszenia broni palnej ${ }^{24}$. Trybunał nie podejmuje żadnych działań z urzędu, nie formułuje zasad, według których poszczególne państwa powinny stanowić i stosować prawo. Do zadań ETS nie należy także dokonywanie analizy stanu przestrzegania praw człowieka w państwach członkowskich, a przez to urzeczywistnianie zasady równouprawnienia. "Jego rola ogranicza się do orzekania, czy w konkretnych okolicznościach indywidualnej sprawy nie doszło do naruszenia praw jednostki" ${ }^{25}$.

Wyrazem polityki Unii Europejskiej na rzecz zapewnienia równych szans dla kobiet jest opublikowany w 1996 roku przez Komisję Europejską dokument pt. „Włączenie problematyki równych szans do polityk unijnych i działań wspólnotowych". W akcie ukazano spójny i całościowy system oparty na zasadzie tzw. gender mainstreaming. Oznacza uwzględnianie wpływu unijnych strategii na problematykę płci przy ocenie owych działań politycznych. W ramach zasady gender mainstreaming promowane jest hasło równouprawnienia i równości płci oraz adekwatnego do możliwości partnerów podziału obowiązków rodzinnych i zawodowych. „Dla przykładu elementem polityki regionalnej są działania nastawione na poprawę stanu zatrudnienia i walkę z bezrobociem. Ponieważ kobiety statystycznie są w większym stopniu dotknięte stanem bezrobocia, specjalne środki z Europejskiego Funduszu Społecznego są przeznaczane na specjalne inicjatywy związane ze statusem kobiet"26.

23 A. M. Świątkowski, op. cit., s. 144.

24 Ibidem, s. 143-144.

25 M. Krzyżanowska-Mierzewska, op. cit., s. 13.

26 www.federa.org.pl. 


\section{Pozostałe instrumenty unijne}

Działalność UE na rzecz wyrównywania szans obu płci nie dotyczy wyłącznie rynku pracy. Instrumenty wspólnotowe przeciwdziałają nierównościom między kobietami i mężczyznami w wielu obszarach życia. W systemie europejskim dwojakie zabezpieczenia mają na celu rozwinięcie i przestrzeganie zasady równości i niedyskryminacji. „Po pierwsze, nie traktuje się zasady niedyskryminacji jako autonomicznego prawa, a jej naruszenie rozpatruje się w koniecznym kontekście naruszenia jakiegoś substancjalnego prawa chronionego. Po drugie, zasada niedyskryminacji nie wyklucza różnic traktowania, pod warunkiem, iż jest po temu rozsądne i obiektywne uzasadnienie. Arbitralna, bezpodstawna dyskryminacja jest, oczywiście wykluczona"27.

Ewidentną przewagą Unii jest fakt, iż lata aktywnej działalności środowisk kobiecych uświadomiły społeczeństwom Europy Zachodniej, iż dyskryminacja może być nie tylko bezpośrednia. Owe pośrednie formy są znacznie trudniejsze do wykrycia. UE wciąż podejmuje realne działania, zarówno w omawianych wcześniej wspólnotowych ustawodawstwach antydyskryminacyjnych, które narzucają pewne minimalne standardy, a także na szczeblu poszczególnych państw, które niejednokrotnie rozwijają wymagane zagadnienia oraz w ogólnych strategiach rozwoju.

Priorytetem Agendy Lizbońskiej, jako ogólnej strategii rozwoju, jest „podniesienie wskaźnika zatrudnienia kobiet do 60 procent potencjalnej żeńskiej siły roboczej w 2010 roku. Ma to na celu podniesienie ogólnego wskaźnika zatrudnienia w Unii Europejskiej. Biorąc pod uwagę, że średni wskaźnik zatrudnienia wynosi w Unii niecałe 55 procent, bardzo dużo wciąż pozostaje do zrobienia. Osobnym zagadnieniem jest problematyka jakości miejsc pracy" 28 . Jest to zagadnienie, do którego UE przywiązuje ogromną wagę, gdyż równouprawnienie jest nierozerwalnie związane z dyskryminacją kobiet na rynku i w miejscach pracy. Danuta Hübner na Konferencji „Sukces jest rodzaju żeńskiego” przedstawiła miejsce pracy o wysokiej jakości jako stanowisko, na którym jednostka może optymalnie rozwijać swoje zdolności, zainteresowania, a także podnosić kwalifikacje oraz realizować ambicje i plany. UE daje możliwość korzystania $\mathrm{z}$ doświadczeń innych, poprzez porównanie określonych strategii równo-

27 Leksykon.

28 D. Hübner, Konferencja ,,Sukces jest rodzaju żeńskiego. Równy status kobiet i mężczyzn", Rzeszów, 7 marca 2003 r. 
uprawnienia $\mathrm{w}$ poszczególnych krajach członkowskich oraz różnorodnych modeli instytucjonalnych. Celem jest tzw. dobra praktyka, której służy Wspólnotowa Strategia Ramowa w sprawie Równości Płci.

\section{Kobiety w Polsce}

Położenie kobiet w Europie Środkowej i Wschodniej za czasów komunizmu, całkowicie różniło się od sytuacji kobiet na Zachodzie. Promowanie przez ideologię komunistyczną ,równości” płci oraz dążenie do jak najbardziej pełnego zatrudnienia sprawiło, iż udział kobiet w rynku pracy był wysoki. „Mniej więcej od 1950 roku rządy kładły nacisk na równość między kobietami i mężczyznami, zachęcając kobiety do zdobywania takiego samego wykształcenia i odgrywania identycznych ról na rynku pracy"29. W rzeczywistości główną motywacją kobiet był fakt, iż w związku z ogólnie niskim poziomem wynagrodzeń oboje małżonkowie byli zmuszeni do pracy zarobkowej.

W okresie transformacji ustrojowej sytuacja uległa zmianie. Część kobiet, głównie gruntownie wykształconych, mogła skorzystać z szans, jakie przyniosła nowa sytuacja polityczna. Niepewność zatrudnienia i dochodów w większym stopniu zaczęła dotyczyć kobiet niż mężczyzn. Powodem tego zjawiska był fakt, iż polityka władz socjalistycznych mająca na celu promowanie równouprawnienia, nastawiona była wyłącznie na podwyższenie liczby kobiet pracujących zawodowo. „Przeważnie nie kwestionowano systemu tradycyjnych norm i wartości, zgodnie z którymi na kobietach spoczywała główna odpowiedzialność za dom. Nie dokonała się istotna zmiana w podziale pracy w rodzinie, a jedynym sukcesem polityki państwowej było zwiększenie udziału kobiecej siły roboczej w niezmienionej strukturze zatrudnienia"30.

Po 1989 roku, sytuacja kobiet w Polsce pogorszyła się. Urszula Nowakowska słusznie stwierdza, iż głównie kobiety zostały obciążone problemami związanymi z transformacją ustrojową. Wynikało to $\mathrm{z}$ faktu, iż reformy gospodarcze i społeczne zostały uznane, jako mające poprawić sytuację wszystkich grup społecznych, za priorytetowe. Wpływ przemian na rzeczywistą sytuację kobiet był drugorzędny. W tym samym okresie konserwatywne siły społeczne i polityczne wzmogły działania mające

${ }^{29}$ Ekonomia i pleć ..., s. 120.

30 Ibidem, s. 133. 
wstrzymać, a wręcz cofnąć starania na rzecz poprawy statusu kobiet w Polsce. Po wielu dyskusjach wprowadzono restrykcyjne prawo, które ograniczyło kobietom dostęp do zabiegów usuwania ciąży. Następnie wycofano ze szkół edukację seksualną, wstrzymano dofinansowanie środków antykoncepcyjnych oraz zaniechano realizacji programów rządowych mających za zadanie promocję awansu i równouprawnienia kobiet ${ }^{31}$.

Tabela 1

Różnice w zarobkach kobiet i mężczyzn w sektorze publicznym i prywatnym według poziomu wykształcenia

\begin{tabular}{||l|c|c||}
\hline \multirow{2}{*}{\multicolumn{1}{|c|}{ Poziom wyksztalcenia }} & \multicolumn{2}{|c|}{ Wskaźnik zarobków kobiet/mężczyzn } \\
\cline { 2 - 3 } & sektor publiczny & sektor prywatny \\
\hline Wyższe & 74,3 & 74,9 \\
\hline Policealne & 77,1 & 85,5 \\
\hline Średnie zawodowe & 76,0 & 81,3 \\
\hline Średnie ogólne & 87,0 & 82,0 \\
\hline Zawodowe & 61,9 & 73,9 \\
\hline Podstawowe i niższe & 63,9 & 79,5 \\
\hline
\end{tabular}

Źródło: Główny Urząd Statystyczny, październik 2001.

Podobne przykłady można rozszerzyć choćby o niepowodzenie przyjęcia ustawy o równym statusie kobiet i mężczyzn, osłabienie gwarancji prawnych powrotu do pracy po urlopie wychowawczym czy nieudana próbę powołania Komisji Parlamentarnej do spraw Równego Statusu. Jednak pomimo wielu trudności, na przestrzeni ostatniej dekady, aktywność kobiet wzrosła, co potwierdza Raport Banku Światowego. Kobiety stanowią szczególną grupę uczestników rynku pracy. Wykazują większą od mężczyzn aktywność w poszukiwaniu zatrudnienia, jednakże mają znacznie mniejsze szanse znalezienia pracy. Prawdopodobnie był to główny powód faktu, iż ,na przestrzeni ostatniej dekady ekonomiczna aktywność kobiet znacznie się rozwinęła: pomiędzy rokiem 1985 i 1998 liczba kobiet prowadzących własną firmę poza rolnictwem wzrosła pięciokrotnie, podczas gdy w podobnym okresie ten sam wskaźnik w przypadku

31 Por. U. Nowakowska, Kobiety $w$ Polsce $w$ latach 90-tych, www.temida.free.ngo.pl/rapawans.htm. 
mężczyzn uległ zaledwie podwojeniu" ${ }^{32}$. Młode kobiety z obszarów wiejskich rozwinęły wiele inicjatyw gospodarczych głównie w agroturystyce, rzemiośle oraz w przetwórstwie i sprzedaży produktów rolnych. Zgodnie z tabelą 2, obecny udział kobiet w ogólnej populacji samozatrudnionych w Polsce należy do najwyższych wśród pozostałych krajów UE.

Tabela 2

Udział kobiet w ogólnej populacji osób samozatrudnionych w Polsce i wybranych krajach UE (uśrednione dane za lata 1990-1997)

\begin{tabular}{|l|c||}
\hline \multicolumn{1}{|c|}{ Kraj } & Udzial w procentach \\
\hline Belgia & 28,9 \\
\hline Finlandia & 31,1 \\
\hline Francja & 26,0 \\
\hline Grecja & 19,4 \\
\hline Hiszpania & 26,8 \\
\hline Holandia & 32,8 \\
\hline Irlandia & 20,1 \\
\hline Niemcy & 28,3 \\
\hline Szwecja & 25,7 \\
\hline Wielka Brytania & 24,8 \\
\hline Włochy & 23,4 \\
\hline POLSKA & 34,0 \\
\hline
\end{tabular}

Źródło: OECD Small and Medium Enterprise.

W raporcie ustalono, iż w ogólnym ujęciu kobiety w Polsce posiadają wyższe wykształcenie od mężczyzn, a także częściej kończą kursy i szkolenia zawodowe. Przejawiają więcej inicjatywy w zakresie działalności gospodarczej, zarówno na terenach miejskich, jak i wiejskich. Z drugiej strony kobiety uzyskują znacznie gorsze dochody z pracy, świadczenia emerytalne i mają mniejsze perspektywy awansu zawodowego. Przeważają wśród osób pracujących w zawodach sektora publicznego o niskim statusie społecznym, a działalność na scenie politycznej pozostaje bardzo ograniczona $^{33}$.

32 Polki tracq-Raport Banku Światowego, „Rzeczpospolita”, z dn. 14.07.2004.

33 Ibidem. 


\section{Krajowe instrumenty prawne}

„Celem polityki wewnętrznej każdego demokratycznego państwa powinna być realizacja zasady równości wszystkich obywateli wobec prawa. Rządy krajów, które aspirują do tego miana, są więc zobowiązane do zwalczania przejawów dyskryminacji i podejmowania wszelkich starań w celu zapewnienia równych szans ludziom obojga płci" ${ }^{34}$. Najskuteczniejszym sposobem realizacji tego zadania są różne rozwiązania prawne. W ustawodawstwie polskim uregulowanie kwestii równouprawnienia obojga płci znalazło wyraz w Konstytucji Rzeczypospolitej Polskiej.

„art. 32.

1. Wszyscy są wobec prawa równi. Wszyscy mają prawo do równego traktowania przez władze publiczne.

2. Nikt nie może być dyskryminowany w życiu politycznym, społecznym lub gospodarczym z jakiejkolwiek przyczyny"35.

„art. 33.

1. Kobieta i mężczyzna w Rzeczypospolitej Polskiej mają równe prawa w życiu rodzinnym, politycznym, społecznym i gospodarczym.

2. Kobieta i mężczyzna mają w szczególności równe prawa do kształcenia, zatrudnienia i awansów, do jednakowego wynagradzania za pracę o jednakowej wartości, do zabezpieczenia społecznego oraz do zajmowania stanowisk, pełnienia funkcji oraz uzyskiwania godności publicznych i odznaczeń” ${ }^{36}$.

Pomimo równościowych zapisów w Konstytucji, równouprawnienie nie stało się przedmiotem realnych działań w sferze życia publicznego. Regulacje powyższych artykułów nie przekładają się na działania praktyczne, gdyż w art. 33.2 zawarto jedynie przykładowe sytuacje „w których ma być realizowana zasada równości wobec prawa kobiet i mężczyzn"37. Brakuje prawnych mechanizmów oraz odpowiednich tzw. modeli dobrych praktyk, które pozwalałyby na skuteczne egzekwowanie powyższej zasady. Bez względu na poprawę stanu przepisów prawnych w zakresie równouprawnienia, rzeczywistość nie uległa zmianie - kobiety nadal są w wyraźnie trudniejszej sytuacji.

\footnotetext{
34 J. Bator, op. cit., s. 6.

35 Por. Konstytucja Rzeczypospolitej Polskiej, Warszawa 2003.

36 Ibidem.

37 Okulary równości, www.kobiety.pl
} 
Ustawa o równym statusie kobiet i mężczyzn z dnia 19 lipca 2002 roku jest wyrazem przekonania, iż obowiązujące w polskim ustawodawstwie mechanizmy nie są w stanie zagwarantować rzeczywistej równości płci i nie zapobiegają dalszej dyskryminacji. Projekt uwidocznił, iż sfera stosunków, w których należy zapewnić równouprawnienie kobiet i mężczyzn, jest bardzo rozległa. Sprecyzowano obszary, w których najczęściej dochodzi do naruszania zasady równości oraz określono sposoby przeciwdziałania im. „Sformułowano w nim między innymi:

- rodzaj zobowiązań wobec władz publicznych różnych szczebli związanych z zapewnieniem obu płciom uczestniczenia w życiu politycznym na zasadach równości;

- zasady - nieznanej wcześniej w polskim ustawodawstwie - tzw. demokracji parytetowej w odniesieniu do gremiów mianowanych;

- reguły równego dostępu do wykształcenia dotyczącej także weryfikacji podręczników i pomocy szkolnych według kryterium równości płci;

- zasadę równego dostępu do pracy zawodowej polegającą na równości szans przy przyjęciu do pracy, jednakowym wynagrodzeniu za pracę tej samej wartości, jednakowych warunkach rozwiązywania stosunku pracy, równych szansach podnoszenia kwalifikacji zawodowych, awansu i pracy w warunkach wolnych od molestowania seksualnego; - regułę równości praw i obowiązków rodzicielskich"38.

Przyjęcie ustawy oznaczałoby wprowadzenie do polskiego ustawodawstwa kategorii dyskryminacji ze względu na płeć. Ustawa stała się przedmiotem debaty. Mimo wielokrotnych zmian dokonywanych w projekcie na skutek krytycznych uwag zgłoszonych przez ekspertów wybranych przez Prezydium Sejmu, ocena rządu była równie negatywna. Do najbardziej krytykowanych rozwiązań w ustawie należała propozycja systemu kwotowego oraz ustanowienia urzędu Rzecznika ds. Równego Statusu wraz ze stosowną komisją. W widoczny sposób potrzeba zmiany oczywistych przejawów dyskryminacji kobiet nie okazała się wystarczająco silna - projekt został odrzucony. O braku odpowiedniej atmosfery dla antydyskryminacyjnych regulacji prawnych, świadczy fakt, iż nawet ówczesny lewicowy premier Włodzimierz Cimoszewicz uznał ten projekt za kontrowersyjny z uwagi na przyzwyczajenie polskiego społeczeństwa do patriarchalnego układu ${ }^{39}$.

38 J. Bator, op. cit., s. 16.

39 Por. E. Jagalska, Godność w kuchni odrodzona, „Trybuna” 05.03.1999 r. 


\section{Nowelizacje}

Polska przystępując do Unii Europejskiej, zobowiązała się jednocześnie do przestrzegania zasad ujętych w traktacie powołującym do życia Wspólnoty Europejskie oraz wszelakich dyrektywach zakazujących dyskryminacji. Bez podjęcia działań legislacyjnych zapewniających przestrzeganie zasad równouprawnienia i przyspieszenia prac nad ujednoliceniem prawodawstwa, Polska nie mogłaby zostać członkiem Unii Europejskiej. „Jednym z kroków w tym kierunku było uchwalenie ustawy z dnia 22 czerwca 2001 roku o zmianie ustawy o zatrudnieniu i przeciwdziałaniu bezrobociu oraz ustawy o pomocy społecznej (Dz. U. Nr 89, poz. 973). Dodany nowelizacją przepis (art. 6c ust. 1 pkt 3 ustawy o zatrudnieniu i przeciwdziałaniu bezrobociu) uzupełnia katalog zadań wojewody w zakresie przeciwdziałania bezrobociu" 40 .

Wojewoda przy ustalaniu kryteriów wydawania zezwoleń na pracę musi zadbać, by nie zamieścić wymagań, które mogłyby dyskryminować kandydatów, m.in. z powodu płci. „Podobnie informacja pracodawcy o wolnym miejscu zatrudnienia lub miejscu przygotowania zawodowego nie może zawierać wymagań dyskryminujących kandydatów z tego względu (art. 12 ust. 3a)",41. Wśród regulacji zapewniających równość szans obu płci, polskie ustawodawstwo, w ramach ustawy o zatrudnieniu i przeciwdziałaniu bezrobociu oraz projektu ustawy o promocji zatrudnienia i instytucjach rynku pracy, zapewnia również wsparcie kobiet na rynku pracy. Zakres wsparcia obejmuje promowanie ustawicznego inwestowania we własną karierę zawodową i elastycznego podejścia do zawodu, wspieranie przedsiębiorczości oraz samozatrudniania kobiet, wspieranie dostępu kobiet do edukacji, efektywnych szkoleń zawodowych, doradztwa i poradnictwa zawodowego, a także promowanie nowoczesnych standardów i form zatrudnienia oraz programów specjalnych i innowacyjnych.

W tym samym roku uchwalono także rozległą nowelizację Kodeksu pracy z dnia 24 lipca 2001 roku (Dz. U. Nr 128, poz. 1405), która miała najbardziej kompleksowy charakter $\mathrm{z}$ dotychczasowych działań harmonizacyjnych. Nowela, dostosowując ustawodawstwo polskie do prawodawstwa UE, recypuje m.in. dyrektywę 75/117/EWG, dyrektywę 97/80/EWG oraz dyrektywę 92/85/EWG w sprawie wprowadzenia środków niosących poprawę zdrowia i bezpieczeństwa pracy pracownic w ciąży i pracownic,

40 Okulary równości, www.kobiety.pl.

${ }^{41}$ Ibidem. 
które niedawno rodziły lub karmią piersią. „Zdefiniowano pojęcie jednakowej płacy za jednakową pracę. Wynagrodzenie rozumiane jest jako wszystkie składniki wynagrodzenia, bez względu na ich nazwę i charakter, a także inne świadczenia związane z pracą przyznawane pracownikom w formie pieniężnej i innej formie niż pieniężna"42.

Ponadto wprowadzono zasadę odwróconego ciężaru dowodu oraz rozróżnienie dyskryminacji na bezpośrednią i pośrednią. W postanowieniach ustawy przewidziano wymóg udostępniania przez pracodawcę pisemnych informacji dotyczących przepisów o równym traktowaniu zatrudnionych kobiet i mężczyzn na terenie zakładu pracy lub w inny sposób przyjęty w danym zakładzie. Do 31 grudnia 2002 roku zapewniono zgodność regulacji polskich z postanowieniami m.in. dyrektywy 96/34/WE dotyczącej umowy ramowej na temat urlopu rodzicielskiego poprzez przygotowanie nowelizacji rozporządzenia Rady Ministrów z 28 maja 1996 r. w sprawie urlopów i zasiłków wychowawczych.

W celu zapewnienia zgodności polskich przepisów z dyrektywą 79/7/EWG dotyczącą stopniowego realizowania zasady równego traktowania kobiet i mężczyzn w dziedzinie ubezpieczenia społecznego, Sejm RP dokonał nowelizacji ustawy o systemie ubezpieczeń społecznych z 13 października 1998 roku. Uchylono w 1999 roku ustawę z 17 grudnia 1974 r. o świadczeniach pieniężnych z ubezpieczenia społecznego w razie choroby i macierzyństwa oraz uchwalono nową ustawę o świadczeniach pieniężnych z ubezpieczenia społecznego w razie choroby i macierzyństwa, a także przyjęto w 2002 roku nowelizację ustawy z 17 listopada 1964 r. - Kodeks Postępowania Cywilnego.

\section{Pełnomocnik ds. Równego Statusu kobiet i mężczyzn i Polskie Lobby Kobiet}

Kolejnym przykładem przyspieszenia prac nad ujednoliceniem prawodawstwa było powstanie, po utworzeniu rządu Leszka Millera, urzędu Pełnomocnika Rządu do spraw Równego Statusu kobiet i mężczyzn. Pełnomocnikiem, w randze sekretarza stanu, została Izabela Jaruga-Nowacka, posłanka Unii Pracy. Głównym zadaniem jest ,propagowanie i urzeczywistnianie zasady równego traktowania kobiet i mężczyzn we

${ }^{42}$ D. Hübner, Konferencja Sukces jest rodzaju żeńskiego ..., 
wszystkich sferach życia społecznego oraz przeciwdziałanie wszelkim przejawom dyskryminacji za względu na płeć ${ }^{\prime 43}$. Ponadto zadaniem Pełnomocnika jest przełamywanie stereotypów w sferze podziału zawodów na tradycyjnie męskie i kobiece poprzez przygotowywanie i wdrażanie akcji informacyjno-edukacyjnych. Akcje miałyby polegać m.in. na promowaniu równości szans w zawodach i w zakresie wynagrodzeń, propagowaniu idei wykorzystywania indywidualnych zdolności, promowaniu kobiet na kierownicze stanowiska oraz wspieraniu przedsiębiorczości kobiet.

Wśród sfery działań Pełnomocnika leży również promowanie współodpowiedzialności kobiet i mężczyzn oraz partnerskiego modelu w realizacji obowiązków rodzicielskich i domowych. Instytucja Pełnomocnika jest odpowiedzialna za nadzór nad stosowaniem zasady równego statusu płci w projektach aktów prawnych oraz rozwiązaniach resortowych, jak również stosowanych w praktyce. „Na wniosek Pełnomocnika wprowadzono istotne zmiany rozszerzające Narodowy Program Przeciwdziałania i Zwalczania Przestępczości o konkretne cele, działania i zadania. Chodzi tutaj zwłaszcza o skuteczne przeciwdziałanie przemocy w rodzinie, przede wszystkim wobec kobiet i dzieci" ${ }^{44}$. Do chwili obecnej biuro Pełnomocnika do spraw Równego Statusu pozyskało z funduszy unijnych kilkanaście milionów złotych, a w ciągu najbliższych kilku lat będzie mieć do dyspozycji jeszcze ponad 50 milionów złotych, na projekty wyrównujące szanse dyskryminowanych grup. W grudniu 2003 roku Pełnomocnik ogłosił rozpoczęcie drugiego etapu „Narodowego Planu Działań na rzecz Kobiet" na lata 2003-2005 (pierwszy etap obejmowała lata 1997-2001).

Nie można pominąć także roli Polskiego Lobby Kobiet w European Women's Lobby przy przeciwdziałaniu dyskryminacji kobiet we wszelkich dziedzinach życia. Polki mając swój udział i reprezentację w instytucjach i agendach unijnych, mogą podnosić różnorodne problematyki dotyczące praw kobiet i wpływać na proces stanowienia prawa w Unii Europejskiej. EWL, które posiada status konsultacyjny przy Radzie Ekonomiczno-Społecznej Narodów Zjednoczonych oraz przy Radzie Europy, finansowane jest przez Komisję Europejską. Do głównych działań należą:

- „kobiety w procesie podejmowania decyzji;

- kobiety w społeczeństwie informacyjnym;

43 www.kobiety.pl/index.php?option=dzial\&id=11.

44 D. Hübner, Konferencja Sukces jest rodzaju żeńskiego..., 
- zatrudnienie i opieka społeczna;

- przemoc wobec kobiet;

- status prawny kobiet (np. w traktatach wspólnotowych);

- kobiece mniejszości etniczne w UE"45.

Wymienione instrumenty prawne nie odpowiadają jednakże na podstawowe pytanie w jakim stopniu przystapienie do UE wpłynęło na sytuację kobiet w Polsce?

Zgodnie $\mathrm{z}$ rankingami przeprowadzonymi przez Freedom House $(\mathrm{FH})$ na rzecz przestrzegania praw obywatelskich oraz praw politycznych, przyznano Polsce najwyższą ocenę - jedynkę, w siedmiostopniowej skali. $\mathrm{Z}$ drugiej strony na liście państw wolnych od korupcji, sporządzonej przez Transparency International (TI), Polska uplasowała się na 67 miejscu. Organizacje różnie oceniają stan praw kobiet w Polsce. Zdaniem FH pozycja zawodowa kobiet w Polsce ulega nieustannej poprawie. Symbolem pozytywnych zmian była nominacja kobiety - Danuty Hübner na pierwszego członka KE pochodzącego z Polski. Przeciwne stanowisko zajmuje Amnesty International (AI), przywołując raport Komitetu Praw Człowieka ONZ, zgodnie, z którym kobiety nadal nie są zatrudniane i awansowane na takich samych zasadach jak mężczyźni. Natomiast wszystkie organizacje są zgodne na temat przemocy w rodzinie - Polska niewystarczająco radzi sobie ze zjawiskiem, a ochrona ofiar jest znikoma ${ }^{46}$. Zaś zgodnie $\mathrm{z}$ raportem Banku Światowego, sytuacja kobiet aktywnych zawodowo jest nadal znacznie uzależniona od tradycyjnej, podwójnej roli, jaką kobiety mają spełniać zgodnie ze stereotypowym wzorcem życia rodzinnego ${ }^{47}$.

Ponadto, jak zauważyła Pierella Paci, status kobiet w życiu zawodowym jest upośledzony z uwagi na deficyt środków publicznych, który w okresie pogarszającej się koniunktury ekonomicznej i trudności związanych z restrukturyzacją gospodarczą w szczególnie negatywny sposób dotknął kobiety. „Stopa bezrobocia kobiet wynosi obecnie 20 procent, podczas gdy wskaźnik dla mężczyzn wynosi 17 procent. Polki częściej napotykają na bariery na rynku pracy, gdyż w ogromnej większości obarczone są dodatkowo obowiązkami związanymi z prowadzeniem gospodarstwa domowego"48.

45 www.kobiety.pl/index.php?option=art\&id=4543, www.womenlobby.org.

46 Por. J. Błaszczak, Mapa praw człowieka: Nowi członkowie UE, 12.10.2005, www.e-polityka.pl.

47 Polki traca - Raport Banku Światowego ...,

48 D. Hübner, Konferencja Sukces jest rodzaju żeńskiego ..., 
Wszelakie stereotypy kulturowe znalazły swoje odzwierciedlenie w dyskryminującym ograniczaniu dostępu kobiet do zatrudnienia i awansu zawodowego w Polsce. Dominujący tradycyjny, patriarchalny model rodziny, do którego głównych zwolenników należy Kościół katolicki, powoduje, iż propozycje działań na rzecz równouprawnienia kobiet i mężczyzn oraz przeciwdziałania dyskryminacji ze względu na płeć są postrzegane jako relikt ideologii komunistycznej i potępiane jako sprzeczne z prawem naturalnym. Zdaniem Urszuli Nowakowskiej, fakt, iż emancypacja za czasów komunizmu prowadziła do obarczenia kobiet podwójną odpowiedzialnością, stanowił główną zachętę do ponownego przyjęcia stereotypowych, tradycyjnych ról po upadku komunizmu ${ }^{49}$.

Pierwszoplanową rolą kobiet wciąż pozostało rodzenie i wychowanie dzieci. Zgodnie z przyjętym stereotypem, kobiety mogą podjąć pracę zawodową, jeśli nie będą zaniedbywać swych podstawowych, domowych obowiązków. Dlatego też niezwykle ważne jest uświadamianie kobietom własnych praw i rozwój usług opiekuńczo-wychowawczych, wspomagających oboje rodziców w opiece nad małym dzieckiem.

Nadmiar powolnych oraz niejednokrotnie negatywnych zjawisk nie oznacza jednak, iż po 1989 roku nie doszło do korzystnych zmian w sytuacji kobiet w Polsce. W raporcie Parlamentu Europejskiego oraz Banku Światowego stwierdza się, iż w ogólnym ujęciu, polski system prawny zapewnia równe traktowanie kobiet i mężczyzn. Często brak jest świadomości o istniejących przepisach, co uniemożliwia kobietom pełne korzystanie z przysługujących im uprawnień. „Na tle szybko zmieniającego się krajobrazu legislacyjnego potrzebne są kampanie informacyjne, ze strony nie tylko agend rządowych, ale także organizacji trzeciego sektora" ${ }^{\natural 0}$. Konieczność lepszego informowania kobiet o przysługujących im prawach należy do najczęściej podnoszonych przez raporty m.in. Banku Światowego i Parlamentu Europejskiego.

Społeczeństwo w Polsce nie korzysta w dostatecznym stopniu z możliwości, jakie stwarzają instrumenty unijne. Udział kobiet we władzy i życiu publicznym, równy status kobiet i mężczyzn, równouprawnienie czy dyskryminacja z powodu płci - nadal należą do nowych pojęć, a przez to obcych i niezrozumiałych dla społeczeństwa polskiego. Dodatkowym problemem są szkodliwe stereotypy i fałszywe wizerunki związane z po-

49 Por. U. Nowakowska, op. cit., www.temida.free.ngo.pl/rapawans.htm.

50 D. Hübner, Konferencja Sukces jest rodzaju żeńskiego. ..., 
zycją kobiet i mężczyzn. Polska nadal jest krajem, w którym kobieta jest odpowiedzialna za wychowanie dzieci, opiekę nad osobami starszymi czy niepełnosprawnymi, obowiązki domowe oraz kwestie materialne rodziny. „Dyskurs równościowy dopiero się w Polsce kształtuje i chociaż jego zasięg i znaczenie stopniowo rosną, między promowanym przez wrogów emancypacji wizerunkiem cierpliwej, pokornej i wielodzietnej gospodyni domowej a wyzwoloną i świadomą swoich praw Europejką, o której mówią obrońcy równości, panuje próżnia" ${ }^{, 51}$.

Dalsza restrukturyzacja gospodarki oraz zmiany zachodzące w społeczeństwie muszą uwzględniać wymiar równouprawnienia. Świadczą o tym nie tylko badania, które dowodzą, iż podnoszenie statusu kobiet przynosi wymierne korzyści i faktu, iż dokonujące się zmiany gospodarcze i społeczne przeczą tradycyjnemu podziałowi ról, ale także zobowiązania podjęte przez Polskę w stosunku do UE. Nowoczesna demokracja nie może funkcjonować bez przyswojenia i realizowania zasady równouprawnienia.

$\mathrm{Z}$ analizy zagadnienia statusu kobiet w Polsce na tle unormowań wspólnotowych, można sformułować następujące wnioski i uogólnienia:

1. Zasada równości i niedyskryminacji nie powinna być traktowana mechanicznie. Jej zadanie polega na uwidocznieniu kobietom odrębności ich położenia w celu lepszego zrozumienia natury dyskryminacji oraz stworzenia określonych preferencji zatrudnienia.

2. Poprawa sytuacji ekonomicznej i prawnej, nie tylko w Polsce, ale w całej Europie, wymaga podjęcia znacznie większych niż dotychczas działań politycznych. Istotne znaczenie mają inicjatywy podejmowane zarówno na rynku pracy, w instytucjach państwowych oraz w informowaniu społeczeństwa.

3. Należy zrewidować ogólne społeczno-ekonomiczne dyskursy polityczne popierane przez UE, gdyż w dużym stopniu kolidują z poprawą sytuacji kobiet.

4. Różnorodne inicjatywy podejmowane przez wspólnoty na rzecz równych szans kobiet i mężczyzn zbyt wolno zmieniają rzeczywistość. Dopóki istnieje różnica między kobietami i mężczyznami w zakresie obowiązków domowych, czyli pracy nieodpłatnej, wyeliminowanie tradycyjnych struktur zajmie jeszcze dużo czasu.

51 J. Bator, op. cit., s. 43. 
5. Pełne wykorzystanie zdolności obu płci mogłoby zostać zapewnione przez odpowiednie standardy zabezpieczenia społecznego oraz system monitorowania sytuacji kobiet.

6. Możliwości UE w rozszerzaniu zasady równości i niedyskryminacji w stosunkach pracy ulegają wyczerpywaniu się. „Dalszy postęp w tej sferze jest łączony z aktywnością partnerów społecznych, prowadzących dialog społeczny, obejmujący zagadnienia jednakowego traktowanie pracowników bez względu na płeć, zawierających porozumienia normatywne ustanawiające zakaz dyskryminacji i wprowadzające sankcje prawne za niestosowanie się do poczynionych ustaleń"52.

7. Główna przyczyna ograniczania wpływu wprowadzanych w życie przepisów prawnych $\mathrm{w}$ zakresie równego statusu płci są stereotypy społeczne. Wynika stąd potrzeba zmian w metodzie selekcji pracowników, w programach nauczania, w rozwinięciu sieci opieki nad dziećmi i osobami starszymi.

\section{Summary}

The issue of human rights and fundamental liberties in numerous realms of life whether political and civic, or social and cultural - has been frequently emphasized when discussing the achievements of Western civilization. As a matter of principle, every citizen, regardless of gender, has the same rights, obligations and opportunities in every sphere. This equality implies an equal division of authority and power, that gives women the right to participate in the institutions and public fora that make decisions and issue opinions. This also refers to all other spheres and includes such matters as the right to non-discrimination at work, in business activity, and equal opportunities to obtain material independence.

Polish society still does not take sufficient advantage of the opportunities provided by EU instruments. The participation of women in public authorities and public life, the equal status of men and women, equality of rights, or gender-related discrimination are still new ideas, which are both strange and incomprehensible for Polish society. Another problem is posed by harmful stereotypes and false images related to the position of men and women. Poland remains a country where women are responsible for bringing children up, caring for the elderly or the handicapped, household chores, and for material matters pertaining to the family.

52 A. M. Świątkowski, op. cit., s. 140. 